\title{
INFLUENCE OF CEMENT SOLIDIFICATION AGENT AND SLURRY DENSITY ON MECHANICAL PROPERTY OF LIQUEFIED STABILIZED SOIL
}

\author{
Yujie Cui ${ }^{1}, *$ Yukihiro Kohata ${ }^{1}$ and Weichen Liu $^{2}$ \\ ${ }^{1}$ Graduate School of Engineering, Muroran Institute of Technology, Japan \\ ${ }^{2}$ Department of Civil Engineering, University of Tokyo, Japan \\ *Corresponding Author, Received: 30 March 2020, Revised: 19 April 2020, Accepted: 30 April 2020
}

\begin{abstract}
The traditional Liquefied Stabilized Soil (LSS) is easy to occur brittle failure with the increase of cement content and it was found that the addition of fiber content might improve the brittle property of the LSS. Recently, the LSS produced with lower slurry density than standard slurry density is often used to reduce the overburden pressure during the in-situ constructions which may cause several problems. Therefore, in this study, a series of triaxial compression tests were conducted on LSS specimens prepared in different slurry densities of $1.216,1.280 \mathrm{~g} / \mathrm{cm}^{3}$, cement content of $80,100 \mathrm{~kg} / \mathrm{m}^{3}$ and the fiber content of $0,10 \mathrm{~kg} / \mathrm{m}^{3}$. The results of undrained triaxial tests showed that slight decrease of slurry density can decrease the peak stress of LSS remarkably. Meanwhile, the changing in cement content can affect peak strength as well as the decreasing rate of $E_{\text {tan }} / E_{0}$ in the early loading stage. In addition, by adding fiber material, the local damage caused by shearing and the brittleness were improved. Based on these results of the triaxial tests and unconfined compression tests, the influences of changing in slurry density, as well as added amount of fiber on the triaxial shear properties of the LSS with different cement contents, are discussed in detail.
\end{abstract}

Keywords: Liquefied stabilized soil, Slurry density, Cement content, Fiber material, Triaxial shear property

\section{INTRODUCTION}

As a cement treated soil classified as a slurry premixed soil, Liquefied Stabilized Soil (LSS) [1] is widely utilized as a backfill material in construction site. However, it was found that with the increase of added amount of cement stabilizer, an increase in strength is observed while the seismic resistance might decrease due to its brittleness [2, 3]. On the other hand, in order to reduce the overburden pressure when the LSS is used as a backfill soil for cut and cover tunnel etc., there is a concern about the use of the LSS prepared with a relatively lower slurry density with considering the strength reduction. However, it is considered that some problem might arise for the quality of LSS on the strength, stiffness, durability and so on. In the past, in order to improve the brittle property of the LSS, a series of studies on the Liquefied Stabilized Soil mixed with newspaper prepared like cotton wool as the fiber material was carried out, and it was reported that the brittle property after the peak is improved due to the reinforcing effect of the fiber [4-6]. However, as for decreasing the overburden pressure by preparing the LSS in lower slurry density, it is still not clear about the influence of reduction of slurry density [7].

In this study, based on the triaxial and unconfined compression test, the influence of changing in slurry density and cement content as well as fiber content on the triaxial shear and unconfined compression property of the LSS, are discussed.

\section{MATERIALS AND TESTING METHOD}

\subsection{Test Materials}

In this study, the New Snow Fine Clay (NSFClay) was used as a homogenous base material, which is a commercially available cohesive soil with very clearly defined physical parameters shown in Table 1. Geoset 200 cement provided by Taiheiyo Cement Co. was used as cement stabilizer, which is a cement-based solidifying agent specially for soft clay and problematic soil. Newspaper to be pulverized like cotton wool by a food processor was used as fiber materials (Fig. 1 (left)) which has the same properties as the newspaper. In other words, most content of the fiber are composed of cellulose.

The Liquefied Stabilized Soil used in this study is applied as backfill material which is mainly used below the underground water level. Therefore, it is considered to be able to maintain an inactive state.

Table 1 Physical parameters of NSF-CLAY

\begin{tabular}{cc}
\hline Physical parameters & Values \\
\hline Particle density $\rho_{\mathrm{s}}\left(\mathrm{g} / \mathrm{cm}^{3}\right)$ & 2.762 \\
Liquid limit $\mathrm{W}_{\mathrm{L}}(\%)$ & 60.15 \\
Plastic limit $\mathrm{W}_{\mathrm{P}}(\%)$ & 35.69 \\
Plasticity index $\mathrm{I}_{\mathrm{P}}$ & 24.46 \\
\hline
\end{tabular}



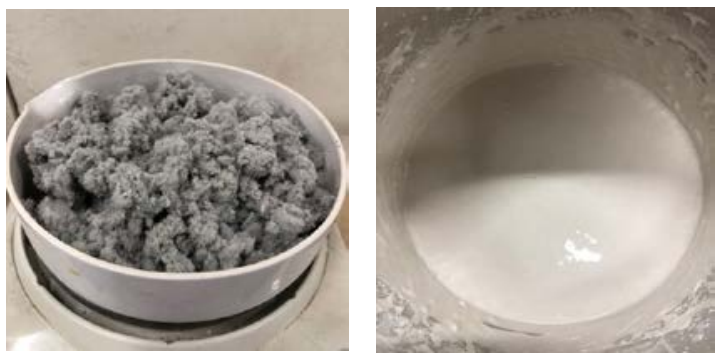

Fig.1 Pulverized newspaper (left) and slurry (right)

\subsection{Mixing Method}

In general, there are two LSS mixing methods used for excavated soil, which are slurry type consisting of an excavated soil, water and cement stabilizer, and adjustment slurry type consisting of the contents of slurry type LSS and fine-grained sand or clayey soil powder. In this study, the slurry type was used due to easier preparation (Fig.1 (right)). In this method, water was added moderately to soil for adjusting a slurry density, then the cement stabilizer was added and mixed. The general mixing test of slurry type LSS were conducted with changing slurry density and cement contents. The slurry density is defined as the mass of slurry divided by the volume of slurry. The slurry is prepared by mixing clay with water.

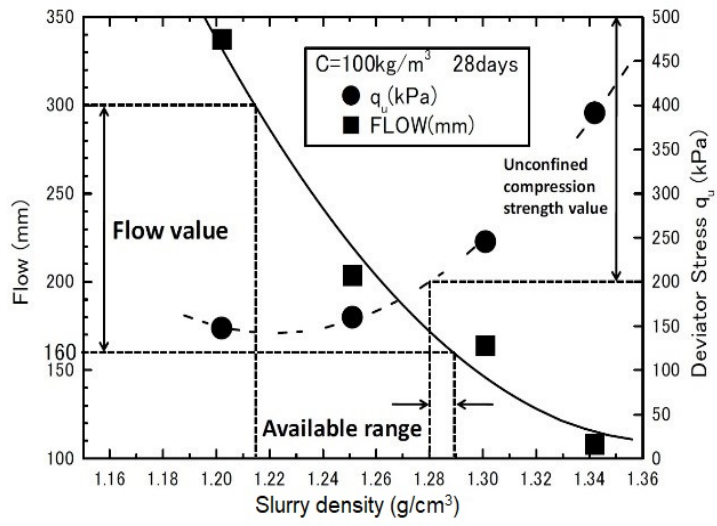

Fig.2 Available range of slurry density [5]

Thus, based on the result of flow test, breathing test and unconfined compression test after 28-days curing, an available range of slurry density as shown in Fig. 2 was drawn with the flow value and unconfined compressive strength. As shown in the figure, this range was carried out with a cement content of $100 \mathrm{~kg} / \mathrm{m}^{3}$ and the unconfined compressive strength after 28-days curing. With the available range of unconfined compressive strength of $200 \sim 500 \mathrm{kPa}$ and flow value of $160 \sim 300 \mathrm{~mm}$, the basic slurry density in this study was decided to be $1.280 \mathrm{~g} / \mathrm{cm}^{3}$, and a changing rate of slurry density
$D \rho_{f}$ was defined as (Actual slurry density)/ (Basic slurry density) $\times 100 \%$.

\subsection{Preparing Method of Specimen}

By applying the slurry type method, slurry with a target density of 1.280 or $1.216 \mathrm{~g} / \mathrm{cm}^{3}$ (in lower density case $D \rho_{f}=95 \%$ ) was prepared by mixing water and NSF-Clay with the amount calculated beforehand. After reaching the target density by adjusting several times, cement stabilizer was added to the slurry with the amount of 80 and $100 \mathrm{~kg} / \mathrm{m}^{3}$. The adding amount of fiber material was decided to be $10 \mathrm{~kg} / \mathrm{m}^{3}$ based on the previous study by the author's group [3-5]. That is, it is found that the investigation for the influence of fiber material is enough to compare between 0 and $10 \mathrm{~kg} / \mathrm{m}^{3}$ according to a series of triaxial compression test results with different fiber contents of $0,5,10,15$, $20 \mathrm{~kg} / \mathrm{m}^{3}$.

After adding the fiber material, the Liquefied Stabilized Soil was fully mixed with a hand-type mixer. In order to reduce the air bubbles that might be generated during adding the fiber material and mixing, the LSS was vacuumed in a sealed cell under a negative pressure of about $-90 \mathrm{kPa}$ for 30 minutes.

After removing the bubbles, specimen was cured by the plastic mold with the size of $50 \mathrm{~mm}$ in diameter and $100 \mathrm{~mm}$ in height. Then after 28 or 56days curing under constant temperature of around $20{ }^{\circ} \mathrm{C}$ and moderate moisture, consolidated undrained triaxial compression test and unconfined compression test were performed. Details of testing cases are shown in Table 2.

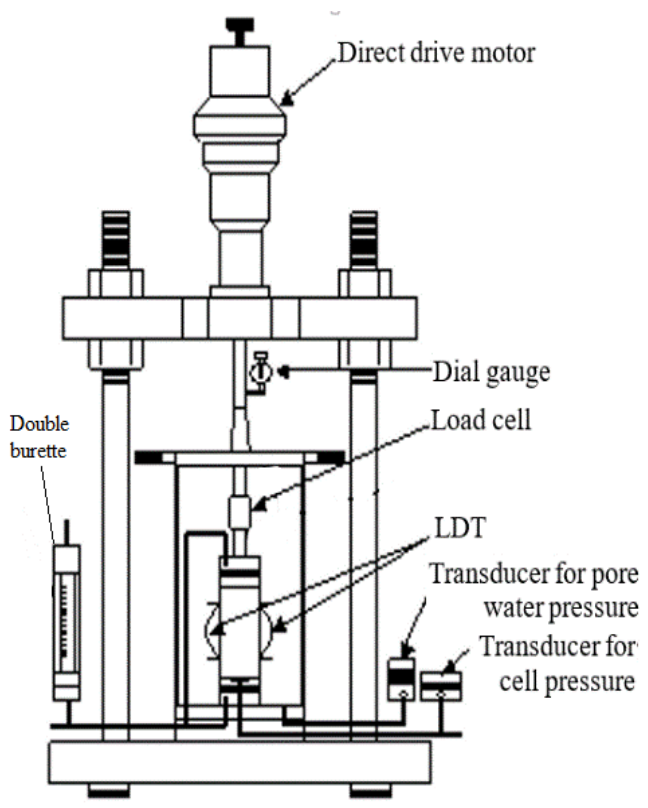

Fig.3 Schematic figure of test apparatus 
Table 2 Details of testing cases

\begin{tabular}{|c|c|c|c|c|c|}
\hline Case ID & $\begin{array}{c}\text { Testing } \\
\text { condition }\end{array}$ & $\begin{array}{l}\text { Curing time } \\
\text { (days) }\end{array}$ & $\begin{array}{c}\text { Cement content } \\
\left(\mathrm{kg} / \mathrm{m}^{3}\right)\end{array}$ & $\begin{array}{l}\text { Slurry density } \\
\left(\mathrm{g} / \mathrm{cm}^{3}\right)\end{array}$ & $\begin{array}{c}\text { Fiber content } \\
\left(\mathrm{kg} / \mathrm{m}^{3}\right)\end{array}$ \\
\hline $\mathrm{T}-28-1$ & \multirow{16}{*}{$\begin{array}{c}\text { Triaxial } \\
\text { compression test }\end{array}$} & \multirow{8}{*}{28} & \multirow{4}{*}{80} & \multirow{2}{*}{1.216} & 0 \\
\hline $\mathrm{T}-28-2$ & & & & & 10 \\
\hline $\mathrm{T}-28-3$ & & & & \multirow{2}{*}{1.280} & 0 \\
\hline $\mathrm{T}-28-4$ & & & & & 10 \\
\hline $\mathrm{T}-28-5$ & & & \multirow{4}{*}{100} & \multirow{2}{*}{1.216} & 0 \\
\hline T-28-6 & & & & & 10 \\
\hline T-28-7 & & & & \multirow{2}{*}{1.280} & 0 \\
\hline T-28-8 & & & & & 10 \\
\hline T-56-1 & & \multirow{8}{*}{56} & \multirow{4}{*}{80} & \multirow{2}{*}{1.216} & 0 \\
\hline T-56-2 & & & & & 10 \\
\hline $\mathrm{T}-56-3$ & & & & \multirow{2}{*}{1.280} & 0 \\
\hline $\mathrm{T}-56-4$ & & & & & 10 \\
\hline T-56-5 & & & \multirow{4}{*}{100} & \multirow{2}{*}{1.216} & 0 \\
\hline T-56-6 & & & & & 10 \\
\hline $\mathrm{T}-56-7$ & & & & \multirow{2}{*}{1.280} & 0 \\
\hline T-56-8 & & & & & 10 \\
\hline U-28-1 & \multirow{8}{*}{$\begin{array}{c}\text { Unconfined } \\
\text { compression test }\end{array}$} & \multirow{4}{*}{28} & & \multirow{2}{*}{1.216} & 0 \\
\hline U-28-2 & & & & & 10 \\
\hline U-28-3 & & & & \multirow{2}{*}{1.280} & 0 \\
\hline U-28-4 & & & & & 10 \\
\hline U-56-1 & & \multirow{4}{*}{56} & 100 & \multirow{2}{*}{1.216} & 0 \\
\hline U-56-2 & & & & & 10 \\
\hline U-56-3 & & & & \multirow{2}{*}{1.280} & 0 \\
\hline U-56-4 & & & & & 10 \\
\hline
\end{tabular}

\subsection{Test Procedures}

As shown in Table 2, laboratory tests were carried out in triaxial undrained conditions and unconfined conditions. For consolidated undrained triaxial compression test, effective confining pressure were controlled to be around $98 \mathrm{kPa}$ with a back pressure of $196 \mathrm{kPa}$ and cell pressure of 294 $\mathrm{kPa}$ in all cases.

A strained controlled triaxial compression test apparatus was used in this test. As shown in Fig. 3, the testing system mainly consists of the axial loading system, loadcell, pressure transducer (for cell and pore water pressure), axial displacement transducer (external dial gauge and local deformation transducer) and volume change measurement (double tube burette). In order to conduct small unloading/reloading loops, direct drive motor (mega-torque motor) with high accuracy was applied in the loading system and all progresses during isotropic consolidation and triaxial shear were controlled by the computer.

The measuring of axial strain in this study was carried out by Local Deformation Transducer (LDT) and Dial Gauge. LDT can measure the axial displacement from small strain level without the bedding error due to the compression of loose layers at the top and bottom ends of specimen or filter paper [8]. Dial Gauge was also used when it exceeds the limited range of LDT.

After setting the LDT with hinges, the specimens were saturated by the double vacuum method, which vacuum pressure was applied and the de-aired water flowed through specimen. After saturation, isotropic consolidation was conducted for 16 hours under the effective confining pressure of $98 \mathrm{kPa}$. In order to study the small strain deformation property, small unloading /reloading loops during monotonic loading were applied before the peak of the stress-strain curve. The axial strain rate was $0.054 \% / \mathrm{min}$ overall. This value was set by reasons as follows. In order to record more data at small strain level, the lowest speed available of the loading system was applied and it is also identical to the author's past study [4-7].

\section{RESULTS AND DISCUSSIONS}

\subsection{Undrained Triaxial Shear Property}

As introduced above, specimen prepared in different slurry density, cement content, fiber content as well as curing time were tested with triaxial apparatus under undrained condition. In this part, the stress-strain relationship and deformation property of the LSS are discussed. 


\subsubsection{Stress-strain relationship}

Figs. 4 to 7 show the stress-strain relationship of all cases carried out with undrained triaxial compression test. Legend in the figure indicates the test condition of the changing rate of slurry density (\%), cement content $\left(\mathrm{kg} / \mathrm{m}^{3}\right)$ and fiber content $\left(\mathrm{kg} / \mathrm{m}^{3}\right)$, respectively.

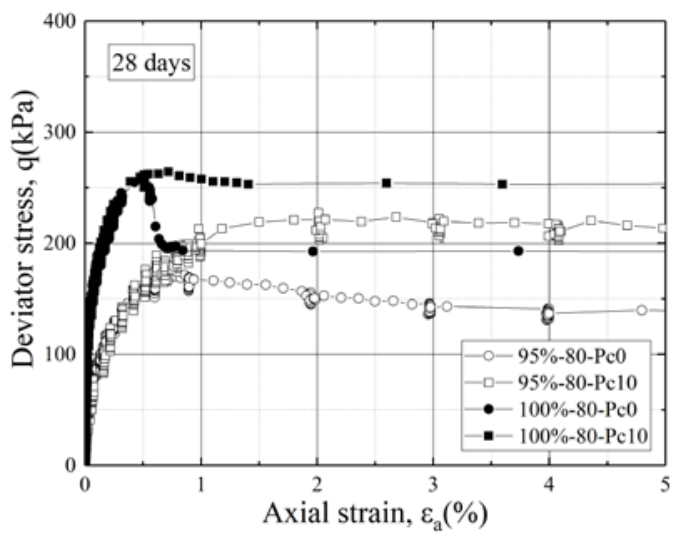

Fig.4 Stress-strain relation of 28 days curing, $\mathrm{C}=$ $80 \mathrm{~kg} / \mathrm{m}^{3}$

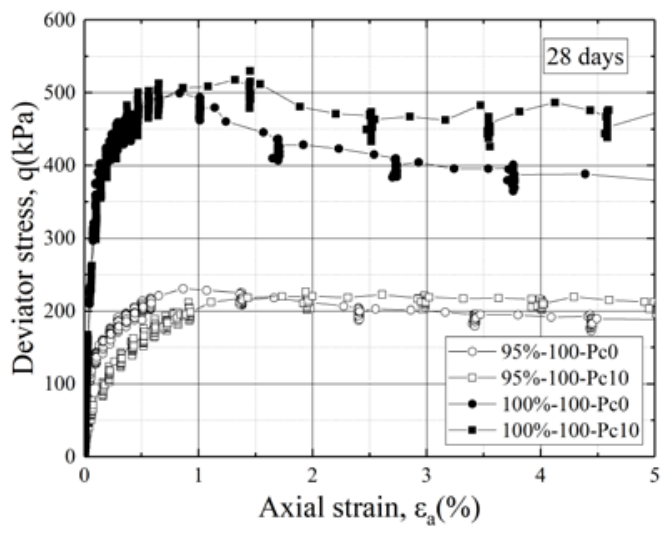

Fig.5 Stress-strain relationship of 28 days curing, C $=100 \mathrm{~kg} / \mathrm{m}^{3}$

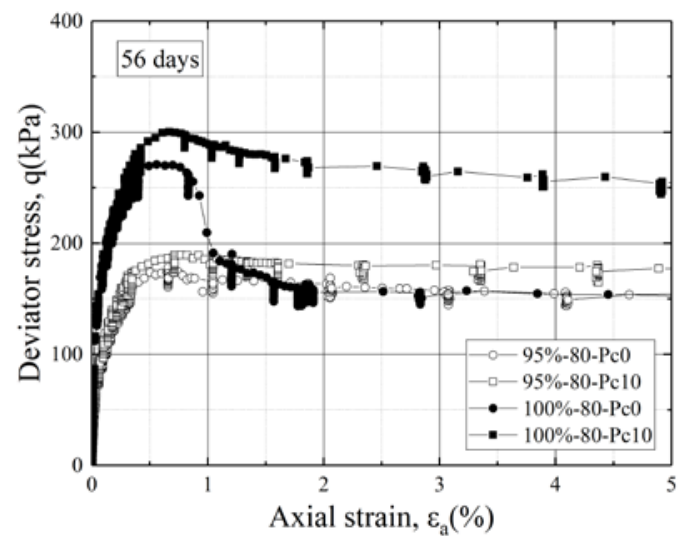

Fig.6 Stress-strain relationship of 56 days curing, C $=80 \mathrm{~kg} / \mathrm{m}^{3}$

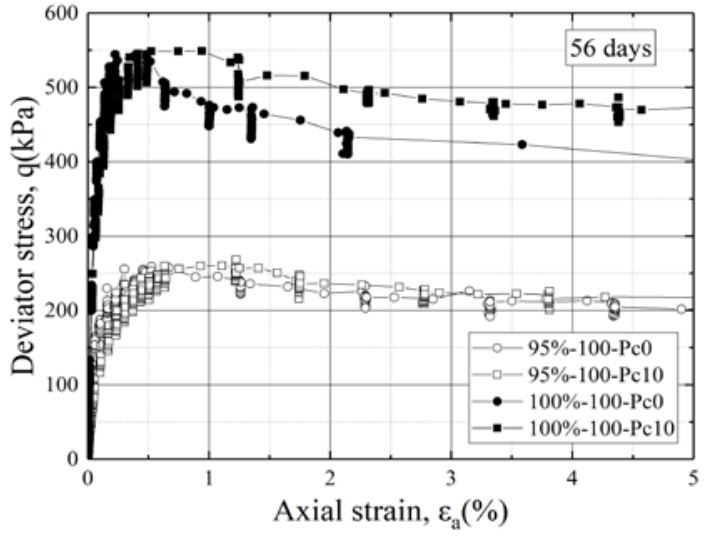

Fig.7 Stress-strain relationship of 56 days curing, C $=100 \mathrm{~kg} / \mathrm{m}^{3}$

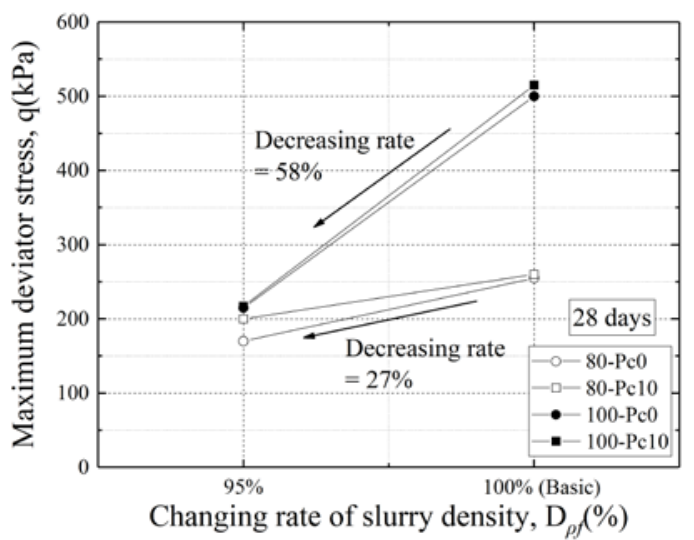

Fig.8 Relationship between maximum deviator stress and changing rate of slurry density (28 days)

In all cases, it can be clearly noticed that the slurry density could significantly influence the strength of the liquefied stabilized soil.

Fig. 8 shows the relationship between maximum deviator stress and the changing rate of slurry density in the case with 28 days curing. This relationship indicates that influence of changing in slurry density is related to the addition amount of cement. With more cement content (line with black symbol), the influence of changing in slurry density was much more significant than that in the cases with lower cement content (line with white symbol). By defining average decreasing rate of maximum deviator stress as (Decreasing value in maximum deviator stress)/ (maximum deviator stress with basic slurry density) $\times 100 \%$, it can be calculated that the decreasing rate with $100 \mathrm{~kg} / \mathrm{m}^{3}$ cement content was 2 times more than cases with $80 \mathrm{~kg} / \mathrm{m}^{3}$ cement.

This result indicates that even if the necessary strength can be satisfied with cement content of 80 $\mathrm{kg} / \mathrm{m}^{3}$ at construction site, it needs to be careful to use liquefied stabilized soil prepared in lower slurry density to decrease the overburden pressure. 
As for the addition of fiber material, it can be noticed that maximum deviator stress increases slightly by adding fibers into the LSS, and the afterpeak behavior is improved in some characteristics. Specimens with fiber generally showed more stable behavior after maximum deviator stress was reached. Meanwhile, not only the after-peak brittleness was improved, but the residual strength of LSS specimens was also increased in most cases.

\subsubsection{Pre-failure deformation property}

In this part, various Young's moduli are applied to discuss the pre-failure deformation properties of the LSS. Different kinds of Young's moduli are defined as shown in Fig. 9

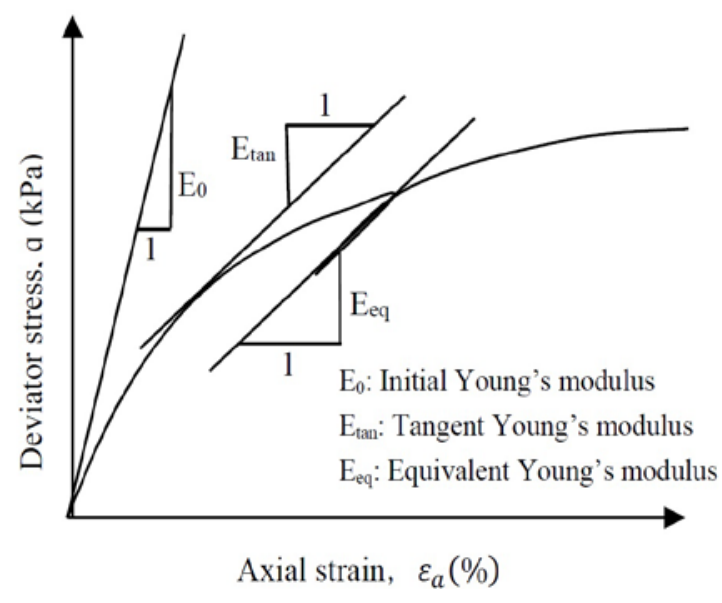

Fig.9 Definition of various Young's moduli

The initial Young's modulus $E_{0}$ is defined as initial stiffness at $\varepsilon_{\mathrm{a}}=0.005 \%$ or less. The tangent Young's modulus $E_{\text {tan }}$ is defined as a tangential gradient in $q \sim \mathcal{E}_{\mathrm{a}}$ curve, it indicates the non-linearity of deformation property in $q \sim \mathcal{E}_{\text {a }}$ relation. The equivalent Young's modulus $E_{\mathrm{eq}}$ is obtained from small unloading/reloading loop during monotonic loading and which can indicate the degree of damage under shearing $[9,10]$.

Figs. 10 and 11 show the relationship between the initial Young's modulus and the cement contents as well as curing times, respectively. Similar as the maximum deviator stress, the initial Young's modulus is also affected by the changing of slurry density. However, the increases in cement content and curing time did not have such significant influence on the initial Young's modulus as to be indicated for maximum deviator stress. In the past study, it is reported that the cement content can affect the initial Young's modulus apparently at lower degree while the influence decrease gradually along with the increase of cement content [5].

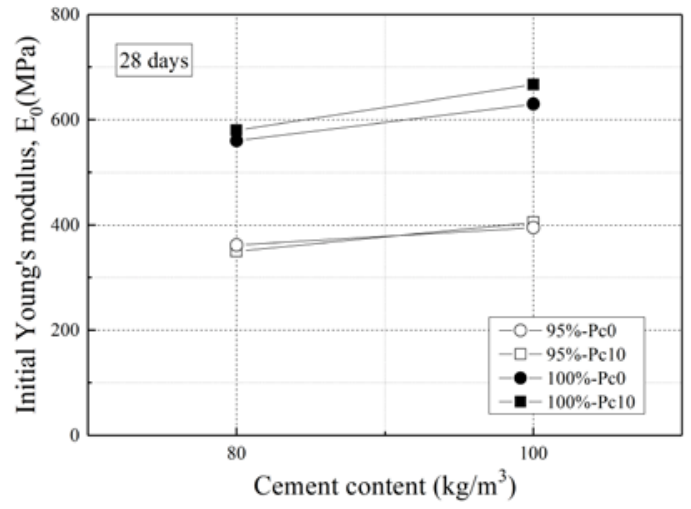

Fig. 10 Relationship between initial Young's modulus and cement contents

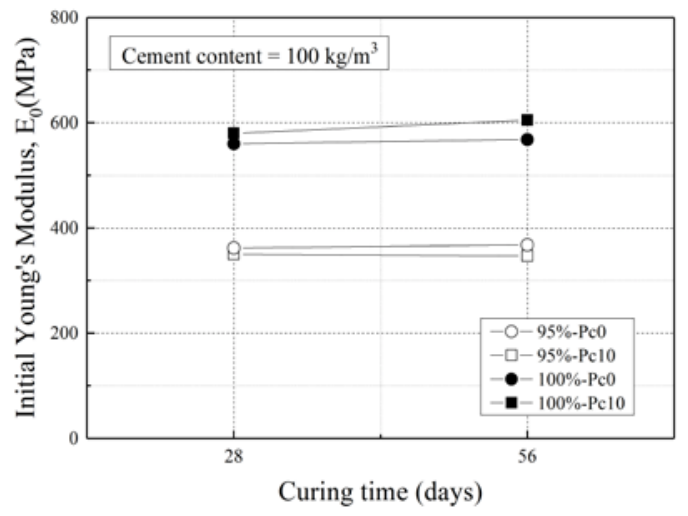

Fig. 11 Relationship between initial Young's modulus and curing times

Figs. 12 to 14 show the relationship between the tangent Young's modulus normalized by the initial Young's modulus $\left(E_{\tan } / E_{0}\right)$ and the deviator stress normalized by the maximum deviator stress $\left(q / q_{\max }\right)$ in different cases. These relations indicate the nonlinearity of pre-failure deformation property. The degree of non-linearity can be compared normalizing the tangent Young's modulus and the deviator stress. It can be noticed that even with the increase of curing time, the decreasing tendency of

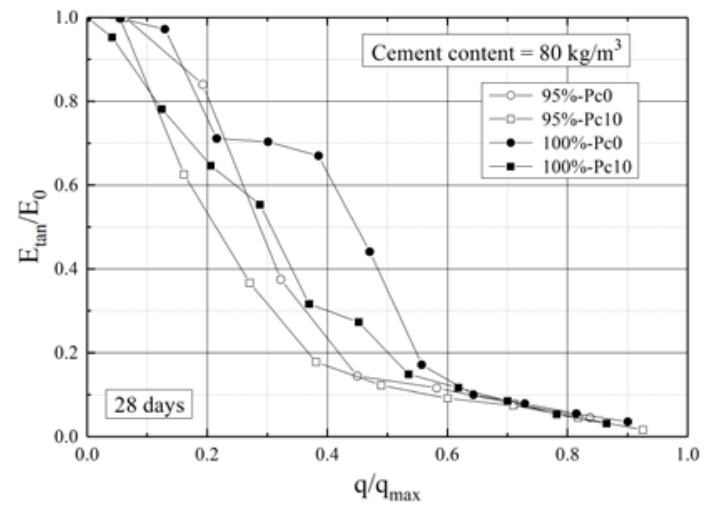

Fig. 12 Relationship between $E_{\tan } / E_{0} \sim q / q_{\max }$ (cement content $=80 \mathrm{~kg} / \mathrm{m}^{3}$, 28 days curing) 


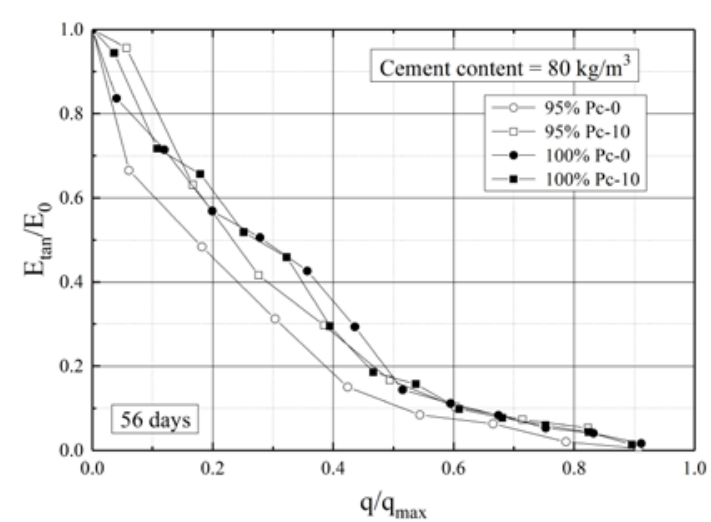

Fig. 13 Relationship between $E_{\text {tan }} / E_{0} \sim q / q_{\max }$ (cement content $=80 \mathrm{~kg} / \mathrm{m}^{3}$, 56 days curing)

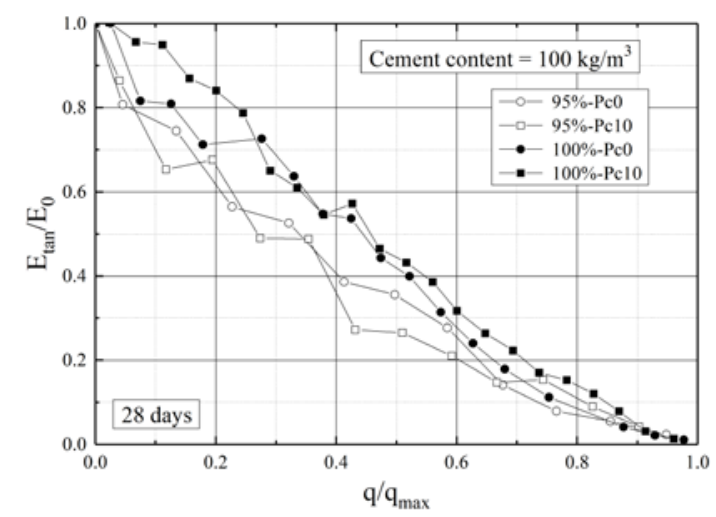

Fig. 14 Relationship between $E_{\text {tan }} / E_{0} \sim q / q_{\max }$ (cement content $=100 \mathrm{~kg} / \mathrm{m}^{3}, 28$ days curing)

$E_{\text {tan }} / E_{0}$ is always large in the cases of lower slurry density as well as an increasing tendency of nonlinearity. Meanwhile, by comparing Figs. 12 and 14, it can be found that the decreasing rate of $E_{\tan } / E_{0}$ at the early loading stage becomes lower with the increase of cement content.

The equivalent Young's modulus (obtained with small loops of unloading/) normalized by the initial Young's modulus $\left(E_{e q} / E_{0}\right)$ are shown in Figs. 15 to 17 with the horizontal axis of $q / q_{\max }$. With all the cases of different curing time and added amount of fibers, $E_{e q} / E_{0}$ seems to decrease earlier when the slurry densities are relatively lower. Therefore, the degree of damage with shear seems to be larger in the case of lower slurry density, and that tendency becomes large to be reduced with the addition of fiber materials.

As for the result obtained with higher cement content, the change of cement content from 80 to $100 \mathrm{~kg} / \mathrm{m}^{3}$ do not have noticeable influence compared with that of curing time.

\subsection{Unconfined Compression Property}

As shown in Table 2, specimen prepared in different slurry densities, fiber contents and curing

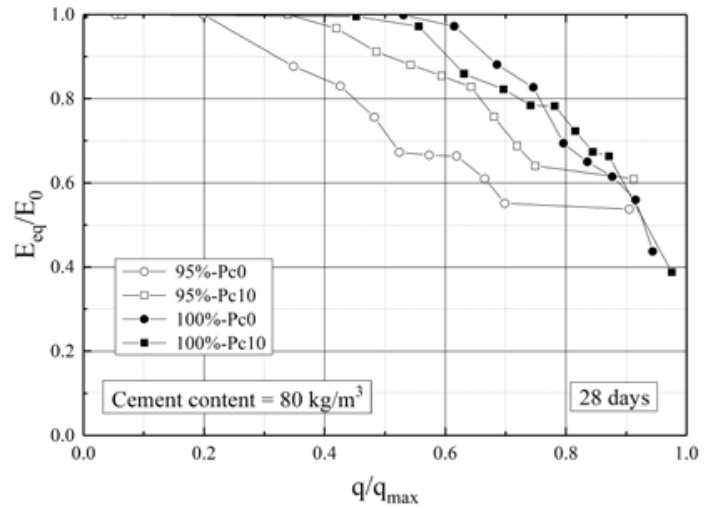

Fig. 15 Relationship between $E_{e q} / E_{0} \sim q / q_{\max }$ (cement content $=80 \mathrm{~kg} / \mathrm{m}^{3}$, 28 days curing)

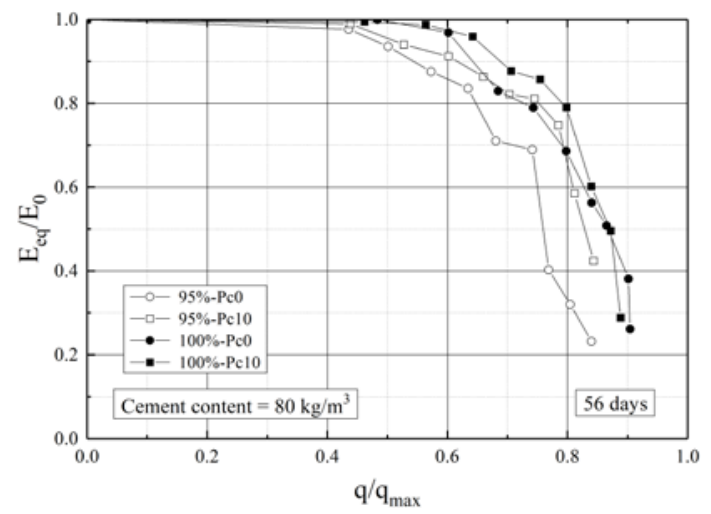

Fig. 16 Relationship between $E_{e q} / E_{0} \sim q / q_{\max }$ (cement content $=80 \mathrm{~kg} / \mathrm{m}^{3}$, 56 days curing)

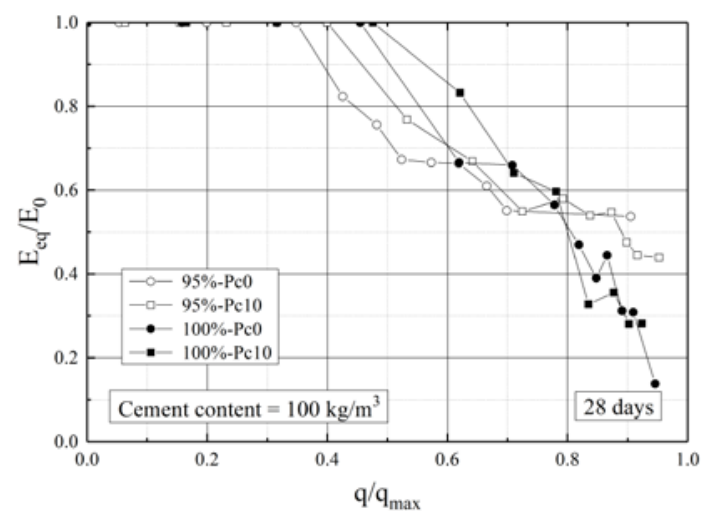

Fig. 17 Relationship between $E_{\text {eq }} / E_{0} \sim q / q_{\max }$ (cement content $=100 \mathrm{~kg} / \mathrm{m}^{3}, 28$ days curing)

times were also tested under unconfined condition. In this part, the unconfined compression property of the LSS is discussed and compared with its triaxial shear property.

The stress-strain relationships of unconfined compression tests are shown in Figs. 18 and 19 with different curing time. As compared to those of triaxial tests, it can be noticed that the maximum deviator stress was not significantly affected in such different confining conditions. This phenomenon 
was reported by Horpibulsuk, Miura and Bergado in 2004 [11] that due to the cement solidification, cementation bond dominated the strength characteristics of the cement mixed soil. However, due to different stress conditions and stress paths that the specimen experienced during tests, large difference in the stress-strain relationships can still be observed from the results of unconfined compression tests.

Specimens with lower slurry density exhibited similar behavior as in triaxial test, but those with higher slurry density showed obvious after-peak brittleness during the test. Meanwhile, effect of fiber reinforcement was not clear, due to the irregular deformation pattern. In some cases with high slurry density, residual strength was even lower than that of specimen with lower slurry density.

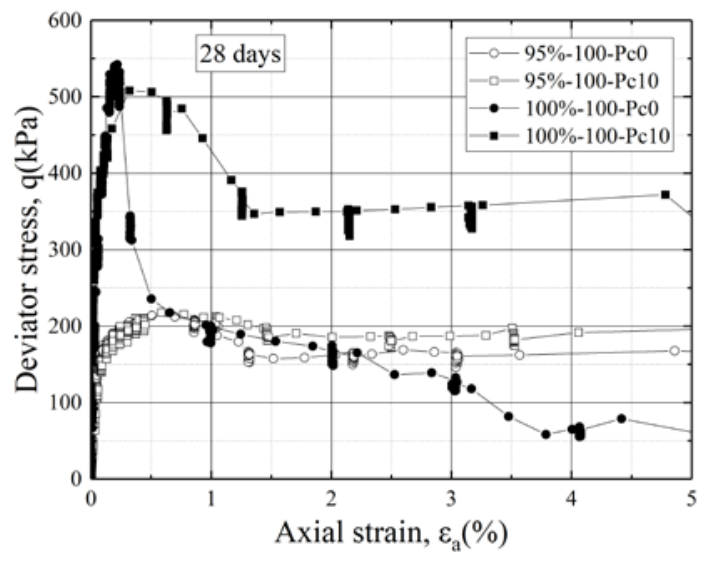

Fig. 18 Stress-strain relationship during unconfined compression test (28 days curing)

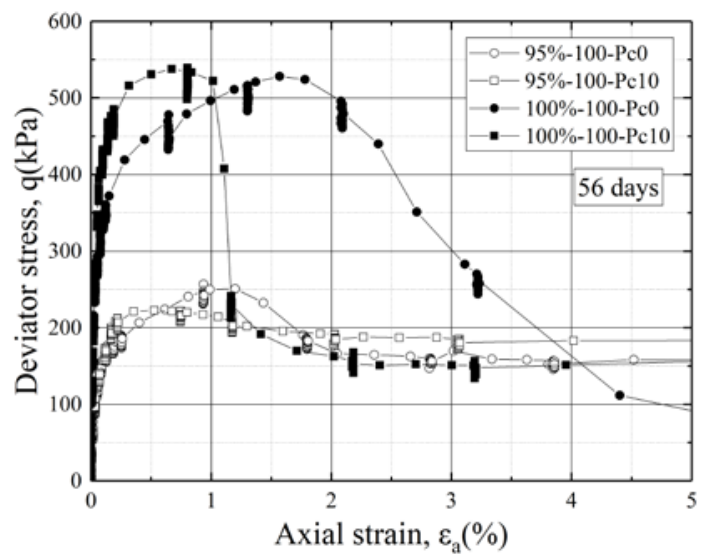

Fig. 19 Stress-strain relationship during unconfined compression test (56 days curing)

Photos of specimens taken after triaxial tests and unconfined compression tests are shown in Figs. 20 and 21 with cracks and shear bands indicated in black lines on the membrane.

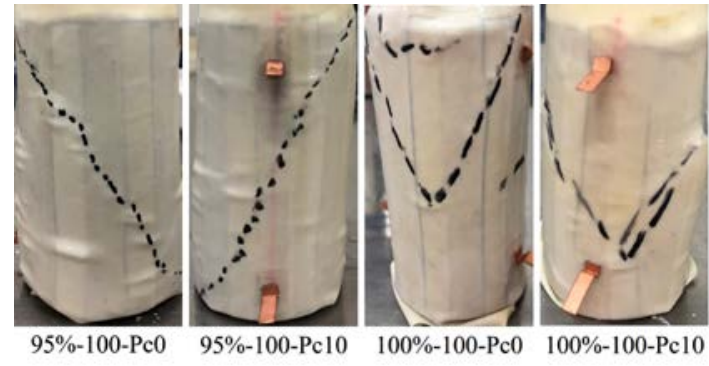

Fig. 20 Specimens after undrained triaxial tests

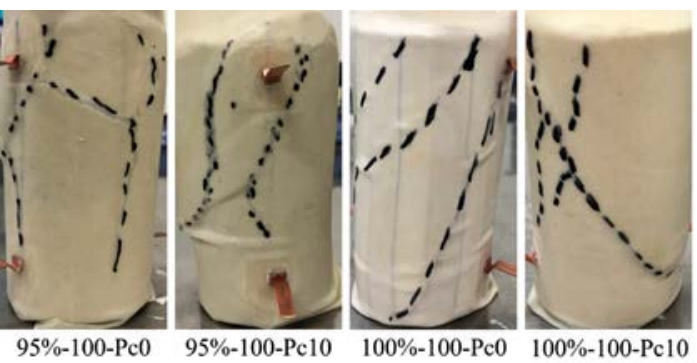

Fig.21 Specimens after unconfined compression tests

Due to the unconfined condition, specimen showed obvious dilatancy in the early loading stage and no clear shear band formed as in triaxial test. But with the increase of slurry density, specimen became more brittle which progressed the formation of shear band.

However, it is still difficult to find evidence which can present the reinforcement of fiber material in these unconfined compression test.

\section{CONCLUSIONS}

This study focused on the mechanical properties of liquefied stabilized soils during laboratory test. With a strain controlled triaxial test apparatus employed, a series of undrained triaxial compression tests and unconfined compression tests were carried out on the LSS specimens prepared in different curing times, slurry densities, cement contents and fiber contents. Based on the test results, following conclusions can be obtained.

1) When the slurry density slightly decreases from the normal slurry density obtained from the standard mix proportion design figure, it is considered that the $q_{\max }$ decreased remarkably. In addition, it is found that the local damage caused by shearing even in the case of lower slurry density is reduced by the fiber material.

2) The test results on specimens with higher cement content indicate that cement content can affect the $q_{\max }$ as same as the slurry density while the fiber material seemed to behave well in these cases to improve the brittleness. 
3) The $E_{\tan } / E_{0} \sim q / q_{\max }$ relationships show that the decreasing rate of $E_{\tan } / E_{0}$ in the early loading stage was influenced by the cement content. In addition, it seems that the addition of fiber materials can also decrease the decreasing rate slightly in all cases.

4) The influence of slurry density on the degree of damage caused by shear is quite large and the degree of damage tends to be reduced by the addition of fiber material.

5) The effect of cement content on the stiffness is relatively small compared with the effect of slurry density, whereas the effect of cement content on the strength is larger than that of slurry density. Therefore, it is considered that even if a cement content increases, the decrease of slurry density causes the reduction of quality for the Liquefied Stabilized Soil.

6) During unconfined compression tests, specimens with lower slurry density show similar behavior as in triaxial tests but with the increase of slurry density, brittleness of specimens may be an increasing.

7) Since no initial effective confining stress existed during unconfined compression test, formation of shear bands and cracks are more irregular than in triaxial test.

\section{ACKNOWLEDGEMENT}

The authors are grateful for the funding awarded by the Geo-Science Center Foundation in 2017. And the second author is grateful for the funding awarded by the Japan Ministry of Education, Culture, Sports, Science, and Technology (Grant-inAid for Scientific Research (C) No. 19K04590).

\section{REFERENCES}

[1] Kuno, G., eds, Liquefied stabilized soil methodRecycling technology of construction-generated soil and mud, Gihodo publication, 1997 (in Japanese).

[2] Japanese Geotechnical Society, Committee Report Chapter 2, 2.1, 2.2 on test methods and physical properties of cement-modified soil, Proc. of symposium, 2005, pp.2-22, on survey, design, construction and properties evaluation methods of solidifying stabilized soil using cement and cement-treated soil (in Japanese).
[3] Kohata, Y., Mechanical property of liquefied stabilized soil and future issues, Doboku Gakkai Ronbunshuu, F, Vol.62, No.4, 2006, pp.618-627 (in Japanese).

[4] Kohata, Y., Ichikawa, M., Nguyen, C. Giang., and Kato, Y., Study of damage characteristics of liquefied stabilized soil mixed with fibered material due to triaxial shearing, Geosynthetics Engineering Journal, Vol.22, 2007, pp.55-62 (in Japanese).

[5] Kohata, Y., Ito, K., and Koyama, Y., Effect of cement content on shear properties of liquefied stabilized soil reinforced by fiber material, Japanese Geotechnical Society Hokkaido Branch Technical Report Papers, Vol.26, 2011, pp.95-100 (in Japanese).

[6] Duong, Q. Hung., Kohata, Y., Omura, S., and Ozaki, K., Strength and deformation characteristics of liquefied stabilized soil reinforced by fiber material prepared at laboratory and field, Geosynthetics Engineering Journal, Vol.29, 2014, pp.33-40.

[7] Do, T. Anh, Kohata, Y. and Sasaki, M., Effect of slurry density on triaxial compressive properties for liquefied stabilized soil reinforced with fiber material, Geosynthetics Engineering Journal, Vol.33, 2018, pp.15-22.

[8] Goto, S., Tatsuoka, F., Shibuya, S., Kim, Y-S., and Sato, T., A simple gauge for local small strain measurements in the laboratory, Soils and Foundations, Vol.31, No.1, 1991, pp.169-180.

[9] Kohata, Y., Tatsuoka, F., Wang, L., Jiang., G-L., Hoque, E. and Kodaka, T., Modelling of nonlinear deformation properties of stiff geomaterials, Geotechnique, Vol. 47, No. 3, 1997, pp. 563-580.

[10] Kohata, Y., Jiang, G-L., Murata, O., and Tatsuoka, F., Elastic-properties-based modeling of non-linear deformation characteristics of gravels, Proc. Of the second Inter. Symposium on Pre-Failure Deformation Characteristics of Geomaterials-IS Torino 99, 1999, pp. 533-539.

[11] Horpibulsuk, S., Miura, N., Bergado, D.T., Undrained shear behavior of cement admixed clay at high water content, Journal of Geotechnical and Geoenvironmental Engineering, Vol.130, No.10, 2004, pp.10961105.

Copyright (C) Int. J. of GEOMATE. All rights reserved, including the making of copies unless permission is obtained from the copyright proprietors. 